\title{
Analysis of Factors Shaping Project Portfolio Management at Indonesia Construction Public State- Owned Enterprise to Increase Workforce Management
}

\author{
Benson*, Rahayu S. Arifin* \\ ${ }^{*}$ Civil Engineering Department, Faculty of Engineering Universitas Indonesia \\ Kampus Baru UI Depok, 16424, Indonesia \\ DOI: 10.29322/IJSRP.11.07.2021.p11540 \\ http://dx.doi.org/10.29322/IJSRP.11.07.2021.p11540
}

\begin{abstract}
Indonesia public construction state owned enterprise (SOE) is Construction Company that owned by the government of Indonesia by $51 \%$ or more. Currently there are 4 Indonesia state owned public construction company. These companies' performance in 2018 are measured by adapting and modifying Malcolm Baldrige Criteria for Performance Excellence (MBCfPE) and putting 2 companies as industry leader, 1 as emerging industry leader, and another as good performance. One of the main reasons for low company performance is poor planning. Project portfolio management (PPM) can increase the planning quality and followed by increasing company performance. The purpose of this study is to analyze the critical success factors for PPM to increase company performance through workforce management with Indonesia public construction SOE as object. The result of this study can lead Indonesia public construction SOE to apply PPM in a better way and increasing the company performance to become industry leader.
\end{abstract}

Index Terms- Indonesia Public Construction State Owned Enterprise, State Owned Enterprise, Critical Success Factor, Project Portfolio Management, Workforce Management.

\section{INTRODUCTION}

$\mathrm{S}$ tate-Owned Enterprises or commonly abbreviated as SOE (BUMN) according to Indonesian Law Number 19 of 2003 are "business entities whose entire or most of the capital is owned by the state through direct investment originating from separated state assets." Over the past 22 years, SOEs have developed with 3 main concepts, namely increasing the value of SOEs, development agents, and synchronizing policies related to SOEs [1]

As the spearhead of the government in developing Indonesia's infrastructure, state-owned enterprises should not ignore the business aspects in carrying out business activities. Along with the increasing contribution of the construction industry to GDP over the past few years in Indonesia [2], the performance of construction companies must improve. In order to measure SOE's performance, the Ministry of SOE uses "Kriteria Penilaian Kinerja Unggul (KPKU)" or Company
Performance Assesment Criteria which is adopted and adapted from the Malcolm Baldrige Criteria for Performance Excellence (MBCfPE). There are 7 criteria to assess the company performance:

1. Leadership

2. Strategic planning

3. Customer focus

4. Knowledge measurement, analysis and management

5. Workforce focus

6. Operation focus

7. Business results.

Assessment of all SOEs is carried out annually in accordance with the 5-year strategic plan issued by the Ministry of SOEs.

One of the main reasons of a project failed in meeting the construction target is poor project planning [3]. Good planning can start from project portfolio management so that an optimization process occurs on the project both in terms of resources and management strategies [4]. The strategic planning process begins with portfolio management which forms the basis of project management and ends with the execution of the project team [5]. However, in practice, these processes are often not aligned, resulting in a waste of resources within the company [5].

In order to maximize the available resources especially workforce, it is necessary to conduct research on the factors that influence the success of project portfolio management to improve workforce efficiency and effectiveness.

\section{THEORITICAL STUDY}

\section{Construction in Indonesia}

As the spearhead of the government in developing Indonesia's infrastructure, state-owned enterprises should not ignore the economic aspects in carrying out business activities of each line of business of SOEs. The current Minister of SOEs, Erick Thohir said, the total profit of 142 SOEs operating in Indonesia reached Rp 210 trillion in 2018. However, only 15 companies out of 34 companies contributed $76 \%$ [6]. Where the dominant companies are in the banking, telecommunications, and oil and gas sectors [7]. This shows that construction SOEs have not yet achieved maximum performance.

\section{Workforce Management}


As one of the criteria to assess company performance, workforce management is also based on KPKU. The goal of the workforce management in KPKU is to assess workforce capabilities and capacities in order to build on friendly working environment with high efficiency [8].

There are two main aspects to be assessed on workforce management $[8]$ :

a. Working Environment

In this category, company need to build effective and supportive working environment. Key point in this assessment are as follow:

- Workforce capability and capacity in relation with the level of competence, skills, distinction, and the number of workforce needed to complete the task required

- Company recruitment program that comply with the company regulation, equality in chances of the new-recruits, and how will the recruit match with the company culture

- Company readiness in workforce shifting to ensure company sustainability and continuous development

- Managing the workforce to ensure all the works needed are completed, making use of company core competence, tightening the customer relation and business and above expectation performance

- To ensure the best available working environment that support workforce health, safety, and accessibility by providing working benefits.

b. Workforce Engagement

To support the sustainability of the company, workforce needed to be retained along with maintaining high performance results. Key point in this assessment are as follow:

- The necessity of company to determine major factors that drives workforce engagement and indicators to assess those engagement

- Company culture to be implemented to the workforce in relevance to increase engagement

- Management system that support high performance environment by giving rewards to the workforce and workforce competence improvement to increase performance

- Workforce career path for company sustainability

\section{Project Portfolio Management}

Project portfolio management is a collection of projects in an organization that compete with each other for the same resources. (Martinsuo \& Lehtonen, 2007). The success of the project is usually often measured by the cost, quality, and time of the project. Recent studies show that factors such as customer satisfaction, organizational performance, future preparation have become a consideration in determining project success where these factors cannot be seen only in aspects of the project but from the perspective of the organization's portfolio (Martinsuo \& Lehtonen, 2007).There are 7 factors that influence the success of project portfolio management:

a. Project Performance
Project performance information allows companies to find out weaknesses and strengths so that optimization can be done to improve project performance [10]. Project performance focuses on the effectiveness of the work on the project rather than the efficiency of the work (Lechler and Dvir, 2010, dikutip dari Kopmann et al., 2015).

b. Synergy Between Projects

Synergy between projects allows each project to share the knowledge and experience gained so that it can be used as guidance and learning for the organization (Nobeoka and Cusmano, 1995, 1997 dikutip dari Abubakar et al., 2018)

c. Portfolio Balance

Portfolio balance is a balance in risk, a balance between opportunities in the near future and in the future, as well as a balance in the resources required for the project (Teller et al., 2012; Killen et al., 2008, dikutip dari Kopmann et al., 2015). According to Cooper et al., (1999) quoted from [13] one of the most important things in project portfolio management to achieve organizational goals is a good allocation of resources.

d. Future Preparation

The company's readiness to face challenges in the future will depend on the competence and technology of the company (Shenhar et al., 2001, quoted from Kopmann et al., 2015). Companies with a high level of quality management, proactive in seeing opportunities, taking measured risks, and having a willingness to close inappropriate projects tend to have better future preparation [14].

e. Business Aspects of the Company

The company's business aspect uses the portfolio as an instrument to increase the value of the company [10]. According to Shenhar et al., (2001) quoted from [13] economic success is divided into market success as reflected in the size of market share and commercial success as reflected in financial indicators such as profits.

f. Business Strategy

The business strategy becomes a reference for project portfolio management to be consistent with the goals of the company so that it can provide competitive advantage, reputation, and widen the business scope [15]. Organizational goals can be achieved if there is good collaboration between business strategy and projects using project portfolio management [5]. Project portfolio management selects projects that are in accordance with the business strategy so that they can maximize value and have a good balance [11].

g. Stakeholders

Stakeholders are an important aspect of project portfolio management because every company strategy requires approval from stakeholders to be implemented [12]. As a state-owned enterprise, the government as one of the company's stakeholders can intervene in the running of the company with existing regulations [16]. One of the important factors in project portfolio management in public SOEs is private investors [16]. 


\section{METHOD}

\section{Reasearch Strategies}

The strategy of this research is to use pragmatism method with qualitative data collection and analysis. The qualitative method was chosen because this research explores through one's experience of situations, actions, and consequences of the research problems raised. In practice, this qualitative research will focus on discussions with respondents regarding the phenomena that occur so that an approach with interview instruments will be used.

\section{Research Stages}

This research will begin with an exploration stage where first the identification of problems that occur in Indonesian public construction SOEs is carried out. After the problems are identified properly, the research is continued by conducting a literature study on the concept of project portfolio management which is expected to provide alternative solutions to the identified problems. Then the formulation of the problem to be discussed in this study can be determined.

The research design is carried out by first determining the research method to be carried out. The research method will explain the stages of research, the variables to be studied, the instruments to be used, data collection methods, data analysis, and determination of conclusions. The method to be used in this study is a qualitative method with descriptive analysis of each object of research where data will be collected by means of structured interviews.

At the research execution stage, data collection will be carried out in 2 stages. Stage 1 is taking expert data with the aim of validating each variable to be used with a structured interview method on the research content and then a descriptive analysis is carried out on the results of the data collection. Phase 2 is collecting data from research respondents using a structured interview method where the data from the interviews will then be analyzed descriptively. After collecting and analyzing the data, conclusions will be drawn from this research.

\section{Population}

The population of the research is professionals who are engaged in construction in public construction SOEs with director positions. The selection of the board of directors (BOD) is due to the large number of discussions regarding the company's strategic matters where the level of the board of directors will have better exposure regarding this matter.

\section{Variables}

There are 2 types of variables used in this study, the independent variable or independent variable $(\mathrm{X})$ which is the critical success factors of project portfolio management and the dependent variable (Y) which is the workforce management criteria of public construction SOE based on KPKU.
Table.1. Portfolio Management Success Factors as Independent Variables (X)

\begin{tabular}{|c|c|c|c|}
\hline $\begin{array}{l}\text { Variable } \\
\text { number }\end{array}$ & $\begin{array}{c}\text { Project } \\
\text { Portfolio } \\
\text { Management } \\
\text { Success } \\
\text { Factors }\end{array}$ & $\begin{array}{l}\text { No Sub } \\
\text { Variabel }\end{array}$ & Variable \\
\hline \multirow[t]{5}{*}{$\mathrm{X} 1$} & \multirow{5}{*}{$\begin{array}{l}\text { Project } \\
\text { Performance }\end{array}$} & $\mathrm{X} 1.1$ & Project profit \\
\hline & & $\mathrm{X} 1.2$ & On budget expense \\
\hline & & $\mathrm{X} 1.3$ & On time project completion \\
\hline & & $\mathrm{X} 1.4$ & Project governance \\
\hline & & $\mathrm{X} 1.5$ & Customer satisfaction \\
\hline \multirow[t]{2}{*}{$\mathrm{X} 2$} & \multirow{2}{*}{$\begin{array}{l}\text { Project } \\
\text { Synergy }\end{array}$} & $\mathrm{X} 2.1$ & Sharing knowledge \\
\hline & & $\mathrm{X} 2.2$ & Sharing resources \\
\hline \multirow[t]{3}{*}{$\mathrm{X} 3$} & \multirow{3}{*}{$\begin{array}{l}\text { Portfolio } \\
\text { Balance }\end{array}$} & $\mathrm{X} 3.1$ & Risk balancing \\
\hline & & $\mathrm{X} 3.2$ & Resouces balancing \\
\hline & & $\mathrm{X} 3.3$ & $\begin{array}{l}\text { Opportunities now and in the } \\
\text { future }\end{array}$ \\
\hline \multirow[t]{3}{*}{$\mathrm{X} 4$} & \multirow{3}{*}{$\begin{array}{l}\text { Future } \\
\text { Preparedness }\end{array}$} & $\mathrm{X} 4.1$ & Potential market share \\
\hline & & $\mathrm{X} 4.2$ & Competency improvement \\
\hline & & $\mathrm{X} 4.3$ & $\begin{array}{l}\text { New technology } \\
\text { development }\end{array}$ \\
\hline $\mathrm{X} 5$ & $\begin{array}{l}\text { Company } \\
\text { Business } \\
\text { Aspect }\end{array}$ & X5.1 & Company financial indicators \\
\hline \multirow[t]{3}{*}{ X6 } & \multirow{3}{*}{$\begin{array}{l}\text { Business } \\
\text { Strategy }\end{array}$} & X6.1 & Corporate strategy alignment \\
\hline & & X6.2 & Organization priority \\
\hline & & X6.3 & Resource allocation \\
\hline \multirow[t]{2}{*}{$\mathrm{X} 7$} & \multirow[t]{2}{*}{ Stakeholders } & X7.1 & Private investors \\
\hline & & $\mathrm{X} 7.2$ & Government \\
\hline
\end{tabular}

Table.2. Workforce Management Assessment Criteria as Dependent Variable (Y)

\begin{tabular}{|c|c|c|c|}
\hline $\begin{array}{c}\text { No } \\
\text { Variable }\end{array}$ & $\begin{array}{c}\text { Dominant } \\
\text { Company } \\
\text { Performance } \\
\text { Assessment } \\
\text { Criteria }\end{array}$ & $\begin{array}{c}\text { No Sub } \\
\text { Variable }\end{array}$ & Sub Variable \\
\hline Y & Workforce Focus & Y1 & Labor Environment \\
\cline { 3 - 4 } & & Y2 & Labor Attachment \\
\hline
\end{tabular}

\section{RESULTS \& DISCUSSION}

\section{Critical Success Factors of Project Portfolio Management (PPM)}

Critical Success Factors (CSF) of the PPM are defined by the assessment from the PPM professionals. 3 experts were interviewed in this study to ensure the factors extracted from the literature study are related in this research. There are 2 questions asked to the expert, those are the relevance of the CSF to PPM and the influence of the CSF towards workforce management. Experts were then asked to fill in the questionnaire and those data were calculated by using descriptive analysis method. The data collected are shown below: 
Table.4 Relevance of PPM CSF and Workforce Management

\begin{tabular}{|c|c|c|c|c|c|}
\hline $\begin{array}{l}\text { Variable } \\
\text { Number }\end{array}$ & $\begin{array}{c}\text { Project } \\
\text { Portfolio } \\
\text { Management } \\
\text { CSF }\end{array}$ & $\begin{array}{l}\text { Sub } \\
\text { Variable } \\
\text { Number }\end{array}$ & Sub Variable & $\begin{array}{c}\text { Relevan } \\
\text { ce of } \\
\text { Variabl } \\
\text { e to } \\
\text { PPM }\end{array}$ & $\begin{array}{c}\text { Will the CSF } \\
\text { effect the } \\
\text { workforce } \\
\text { management } \\
?\end{array}$ \\
\hline \multirow[t]{5}{*}{$\mathrm{X} 1$} & \multirow{5}{*}{$\begin{array}{l}\text { Project } \\
\text { Performance }\end{array}$} & X1.1 & Project Profit & 1.00 & 0.67 \\
\hline & & $\mathrm{X} 1.2$ & $\begin{array}{l}\text { On Budget } \\
\text { Expense }\end{array}$ & 1.00 & 1.00 \\
\hline & & $\mathrm{X} 1.3$ & $\begin{array}{l}\text { On time project } \\
\text { completion }\end{array}$ & 1.00 & 1.00 \\
\hline & & $\mathrm{X} 1.4$ & $\begin{array}{l}\text { Project } \\
\text { Governance }\end{array}$ & 1.00 & 1.00 \\
\hline & & $\mathrm{X} 1.5$ & $\begin{array}{l}\text { Customer } \\
\text { Satisfaction }\end{array}$ & 1.00 & 1.00 \\
\hline \multirow[t]{2}{*}{$\mathrm{X} 2$} & \multirow[t]{2}{*}{$\begin{array}{l}\text { Project } \\
\text { Synergy }\end{array}$} & X2.1 & $\begin{array}{l}\text { Sharing } \\
\text { knowledge }\end{array}$ & 1.00 & 1.00 \\
\hline & & $\mathrm{X} 2.2$ & $\begin{array}{l}\text { Sharing } \\
\text { resources }\end{array}$ & 1.00 & 1.00 \\
\hline \multirow[t]{3}{*}{$\mathrm{X} 3$} & \multirow{3}{*}{$\begin{array}{l}\text { Portfolio } \\
\text { Balance }\end{array}$} & $\mathrm{X} 3.1$ & Risk balancing & 0.67 & 1.00 \\
\hline & & $\mathrm{X} 3.2$ & $\begin{array}{l}\text { Resources } \\
\text { balancing }\end{array}$ & 1.00 & 1.00 \\
\hline & & X3.3 & $\begin{array}{l}\text { Opportunities } \\
\text { now and in the } \\
\text { future }\end{array}$ & 1.00 & 1.00 \\
\hline \multirow[t]{3}{*}{$\mathrm{X} 4$} & \multirow[t]{3}{*}{$\begin{array}{l}\text { Future } \\
\text { Preparedness }\end{array}$} & $\mathrm{X} 4.1$ & $\begin{array}{l}\text { Potential } \\
\text { market share }\end{array}$ & 1.00 & 0.67 \\
\hline & & X4.2 & $\begin{array}{l}\text { Competency } \\
\text { improvement }\end{array}$ & 1.00 & 1.00 \\
\hline & & $\mathrm{X} 4.3$ & $\begin{array}{l}\text { New } \\
\text { technology } \\
\text { development }\end{array}$ & 1.00 & 1.00 \\
\hline $\mathrm{X} 5$ & $\begin{array}{l}\text { Company } \\
\text { Business } \\
\text { Aspect }\end{array}$ & X5.1 & $\begin{array}{l}\text { Company } \\
\text { financial } \\
\text { indicators }\end{array}$ & 1.00 & 0.67 \\
\hline \multirow[t]{3}{*}{ X6 } & \multirow[t]{3}{*}{$\begin{array}{l}\text { Business } \\
\text { Strategy }\end{array}$} & X6.1 & $\begin{array}{l}\text { Corporate } \\
\text { strategy } \\
\text { alignment }\end{array}$ & 1.00 & 0.67 \\
\hline & & X6.2 & $\begin{array}{l}\text { Organization } \\
\text { priority }\end{array}$ & 1.00 & 0.67 \\
\hline & & X6.3 & $\begin{array}{l}\text { Resource } \\
\text { allocation }\end{array}$ & 1.00 & 1.00 \\
\hline \multirow[t]{2}{*}{$\mathrm{X7}$} & \multirow[t]{2}{*}{ Stakeholders } & X7.1 & $\begin{array}{l}\text { Private } \\
\text { investors }\end{array}$ & 1.00 & 0.67 \\
\hline & & $\mathrm{X} 7.2$ & Government & 0.67 & 1.00 \\
\hline
\end{tabular}

Based on the questionnaire, all purposed CSF are relevant with the purposed PPM and those CSF also effect workforce management aspect.

\section{Influence of PPM Factors to Workforce Management}

To further the research, interviews were held with Indonesia public construction SOE's board of directors to calculate the influence of each PPM critical success factor towards workforce management aspect. The influence calculation will be based on the likert scale of 1-5 with scale 1 define as the PPM factor has no influence towards workforce management, while the scale 5 indicates very high influence. The influence is shown in the spider-web analysis below:

\section{Workforce Management}

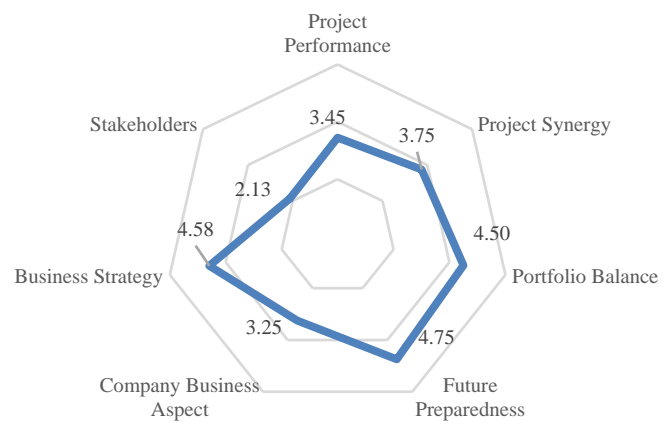

Figure 1 Spider-Web Analysis of PPM Factors to Workforce Management

Based on the figure above, the most influencing factor is the future preparedness where the performance of the workforce will be better if it is accompanied by the provision of good competencies, the development of new technologies that can spur the efficiency of the workforce in carrying out their work and the willingness of the company to try new markets that have good potential in the future. Business strategy and portfolio balance are two supporting variables in improving the performance of workforce focus, where these two variables support the suitability of the workforce's ability to the project portfolio to be implemented and the balance between the required and available resources. Project performance, project synergy, and the company's business aspects also affect the performance of the workforce on a smaller scale, while the stakeholder variables hardly affect the performance of the workforce focus.

For further explanation, the result from the BODs interview are as follow:

- Company with good Future preparedness tend to be able to identify potential markets in the future and getting ready to reach them as soon as possible. The preparation for future markets including workforce training to increase the capacity and capability so that they will be more efficient and effective in future projects. Besides of those work training, providing and updating workforce with latest advance technologies need to be done as they will gives company good advantage and better competitiveness in the future.

- Business strategy as supporting variable gives further improvement towards efficiency and effectiveness of the workforce. Business strategy of a company starts with the compliance of the company long term plan with annual plan. Following the long-term plan, workforce will gradually increase their competence towards the way the company wants to grow. The adjustment of this long-term plan will be shown by the project it takes into company's portfolio. Business strategy also gives company strength in balance resource allocation in each of the project under its portfolio.

- To aim better workforce management, portfolio balance also play significant role. As each project is unique and has its own risk that needs to be balanced, company can provide the best workforce for each project to achieve best solution. Portfolio balance also counts for the opportunities that will 
present in the future and get the company ready to comply with them.

- $\quad$ Project synergy in workforce management also play another important role. Good project synergy gives workforce a platform for sharing knowledge from each project they play part in. Those knowledges will guide workforce from each project to not repeating the same mistake that already been made in other project and provide better solution for unique project problems.

- $\quad$ Project performance factor variables of profit, expense, and time of project completion only have minor effect on workforce management, but project governance and customer satisfaction gives a major effect. Good project governance will have seen the workforce being properly manage and not being wasteful in terms of quantity. While for customer satisfaction, different workforce applied on the same project can lead to different customer satisfaction because each workforce provide different kind of customer engagement and understanding.

- Company Business Aspect variable only has a little effect on workforce management. Company financial indicator only effect the workforce mentality but do not effect on the income they receive.

- While stakeholder is not a significant variable in order to improve workforce management. The stakeholder stated in this research including private investor and the government. Private investors tend to look around the company performance with the focus on financial indicator while government who has the major ownership of the SOE will only effect the company governance.

\section{CONCLUSION}

Based on the current finding of the research and analysis, in order to improve the workforce management, Indonesia construction public SOE needs to make an improvement through this priority scale:

1. Identify potential market that the company can participate in the future,

2. Improving the workforce competence through training and exposure of new construction technology,

3. Aligning the company long-term and short-term strategic plan towards potential market to give workforce more experience in handling those projects,

4. Give more priority to the projects aligned with the company strategic plan and assign best workforce to finish the project,

5. Allocate company resource well,

6. Balancing the risk through appointing the right workforce for specific project type,

7. Providing platform for knowledge sharing between projects and assigning experienced workforce to assist emerging new leaders,

8. Maintaining good governance of each project with aim to increase efficiency and effectiveness.

\section{REFERENCES}

[1] Kementerian BUMN Republik Indonesia, "Laporan Kinerja Kementerian BUMN 2018.” 2018.

[2] R. Maulana, "Sektor Konstruksi Semakin Menggeliat," Bisnis.com, 2018.

[3] M. Sambasivan and Y. W. Soon, "Causes and effects of delays in Malaysian construction industry," Int. J. Proj. Manag., vol. 25, no. 5, pp. 517-526, 2007, doi: 10.1016/j.ijproman.2006.11.007.

[4] R. G. Cooper, S. J. Edgett, and E. J. Kleinschmidt, "New product portfolio management: Practices and performance," IEEE Eng. Manag. Rev., vol. 28, no. 1, pp. 13-29, 2000, doi: 10.1111/1540-5885.1640333.

[5] D. Milosevic, Z. and S. Srivannaboon, "A theoretical framework for aligning project management with business strategy," Proj. Manag. J., vol. 37, 2006

[6] A. Rahma, "Pendapatan BUMN Capai Rp 210 Triliun, 76 Persennya Disumbang 15 Perusahaan," Liputan 6, Jakarta, 2019.

[7] T. Hamdani, "Erick Thohir Soroti Pendapatan Rp 210 T, Mayoritas dari 15 BUMN," Detik.com, Jakarta, 2019.

[8] "Baldrige Excellence Framework," 2017.

[9] M. Martinsuo and P. Lehtonen, "Role of single-project management in achieving portfolio management efficiency," Int. J. Proj. Manag., vol. 25, no. 1, pp. 56-65, 2007, doi: 10.1016/j.ijproman.2006.04.002.

[10] M. Riesener, C. Dölle, G. Schuh, H. Lauf, and M. H. Jank, "Performance-driven and company goal-orientated design of product portfolios: A methodological framework," Procedia CIRP, vol. 84, pp. 725-730, 2019, doi: 10.1016/j.procir.2019.03.267.

[11] J. Kopmann, A. Kock, C. P. Killen, and H. G. Gemunden, "Business Case Control in Project Portfolios - An Empirical Investigation of Performance Consequences and Moderating Effects," IEEE Trans. Eng. Manag., vol. 62, no. 4, pp. 529-543, 2015, doi: 10.1109/TEM.2015.2454437.

[12] S. G. Abubakar, S. G. Dalibi, and Y. Wang, "Factors Shaping Project Portfolio Management in the Nigeria's Built Environment," Int. J. Econ. Commer. Manag. United Kingdom, vol. VI, no. 3, pp. 512-533, 2018, [Online]. Available: http://ijecm.co.uk/.

[13] W. Heising, "The integration of ideation and project portfolio management - A key factor for sustainable success," Int. J. Proj. Manag., vol. 30, no. 5, pp. 582-595, 2012, doi: 10.1016/j.jproman.2012.01.014.

[14] J. Rank, B. N. Unger, and H. G. Gemünden, "Preparedness for the future in project portfolio management: The roles of proactiveness, riskiness and willingness to cannibalize," Int. J. Proj. Manag., vol. 33, no. 8, pp. 1730-1743, 2015, doi: 10.1016/j.jproman.2015.08.002.

[15] L. B. Bai, H. Chen, Q. Gao, and W. Luo, "Project portfolio selection based on synergy degree of composite system," Soft Comput., vol. 22, no. 16, pp. 5535-5545, 2018, doi: 10.1007/s00500-018-3277-8.

[16] C. Chen, Solving the puzzle of corporate governance of state-owned enterprises: The path of the Temasek model in Singapore and lessons for China, vol. 36, no. 2. 2016. 


\section{AUTHORS}

First Author - Benson, Master Candidate, Universitas Indonesia - Civil Engineering Department, Faculty of Engineering; Address: Kampus Baru UI Depok, 16424, Indonesia.

Second Author - Rahayu S. Arifin (Dr), Lecturer, associated Universitas Indonesia - Civil Engineering Department, Faculty of Engineering; Address: Kampus Baru UI Depok, 16424, Indonesia.

Correspondence Author - Benson, benlie95@gmail.com 